Brit. J. industr. Med., 1964, 21, 287.

\title{
EPIDEMIOLOGY OF SKIN DISEASE IN AN AUTOMOBILE FACTORY*
}

\author{
BY \\ MURIEL L. NEWHOUSE \\ From the Department of Occupational Health and Applied Physiology, London School of Hygiene \\ and Tropical Medicine
}

(RECEIVED FOR PUBLICATION MAY 26, 1964)

\begin{abstract}
A survey was made of a random sample of workers from the machine shops, assembly lines, and stock and store departments of an automobile factory. Among the 1,223 men seen, representing $97 \%$ of the sample, the prevalence of non-infective skin diseases was $14.5 \%$. Skin diseases were classified into four groups: 'dermatitis' and 'folliculitis' of occupational origin, endogenous 'eczemas', and miscellaneous skin diseases. Slightly more than half of all the skin diseases seen were considered to be occupational in origin.

In this population the prevalence of skin disease was more than four times that based on patients attending the factory medical department.

An unsuspected cause of allergic dermatitis was found on the assembly lines, where the incidence of dermatitis was significantly higher than among the non-production workers. The prevalence of folliculitis was significantly higher among production than non-production workers. There was no significant difference in the prevalence of 'eczema' or the miscellaneous skin diseases in the various occupational groups.

Among European workers fair men were more prone to skin disease than darker men. In another factory, a West Indian and Asiatic group of workers had a significantly lower prevalence of skin diseases than a group of Europeans doing similar work.

Folliculitis was more prevalent among the younger workers and those recently employed in the factory; there was no obvious association between age and length of service and the occurrence of other types of skin disease.
\end{abstract}

Occupational skin disease is one of the important health problems of modern industry. In Great Britain dermatoses diagnosed as industrial dermatitis' account for the loss of 800,000 working days a year. There are approximately 20,000 spells of sickness absence per year due to this cause. Each spell averages six weeks for men and eight for women (Industrial Dermatitis, H.M.S.O., 1962). The extent of occupational dermatoses not causing sickness absence can only be surmised, but they are a cause of discomfort, anxiety, loss of earning power, and a frequent source of litigation.

It is probable that some of this skin disease is not due to the patients' work. Criteria of diagnosis have

*This survey was supported by a grant from the Medical Research Council and formed part of a thesis submitted for the M.D. of the University of London. not been accurately defined and generally depend on personal opinions. When difficulties in differential diagnosis do arise between an industrial dermatitis and endogenous patterns of skin disease, particularly seborrhoeic or nummular eczema, or other nonoccupational skin disease possibly aggravated by working conditions, the disease may well be classified as industrial in origin and the patient granted disability benefit which is $£ 27 \mathrm{~s}$. $6 \mathrm{~d}$. a week more than sickness benefit.

The present paper describes a survey of workers at risk in a large automobile factory. This investigation followed a survey of patients with skin disease attending the factory medical centres of the same sections of the factory, which took place during the previous year (Newhouse, 1961). In that investigation 425 patients were examined, and the sickness reporting rates of workers with different forms of 
skin disease were studied in relation to their job, age, and length of service in the factory.

For the present survey of workers a one in four random sample, comprising 1,258 men, was chosen. A standard questionnaire was used to record details of identification, age, and length of service, present and past jobs in the factory, a history of past attacks of skin disease, a history of allergic diseases (asthma, hayfever, and eczema), and of the colouring of the hair, eyes, and skin. If a rash was present a diagnosis was recorded. The men were seen in offices on the factory floor near to their place of work. Only the hands, forearms, face, and neck were inspected as a routine. The survey was completed in 10 weeks.

\section{Classification of the Dermatoses Encountered}

For purposes of analysis the diagnoses recorded on the survey sheets were divided into four categories: (1) dermatitis, (2) eczema, (3) folliculitis, and (4) a miscellaneous group. There is much confusion caused by differing interpretations of the terms 'dermatitis' and 'eczema', both of which are used to describe syndromes occurring in the large dermatitiseczema group of skin diseases.

In this report the term 'dermatitis' is used to connote cases of exogenous or contact dermatitis which were diagnosed as having been primarily caused by external agents. It includes both primary irritant (toxic) and allergic dermatitis. The most common manifestation was a red scaly, papular or vesicular eruption affecting the fingers, finger webs, dorsum of the hands, and the wrists and forearms, rarely involving the palms. Dermatitis due to friction was most frequently seen as an erythema of the knuckles associated with the wearing of polyvinyl chloride (plastic) gloves. Defatting agents such as paraffin, white spirit or trichlorethylene produced a marked redness and peeling of the skin.

All types of endogenous eczema were included in the second diagnostic category, 'eczema'. The principal clinical patterns or main groups recognized were atopic eczema, seborrhoeic eczema, nummular eczema, lichen simplex chronicus, and the regional eczemas of which palmar eczema was the most common.

In some instances the differentiation between dermatitis and endogenous eczema inevitably caused difficulties. In these cases the diagnosis was based on an assessment of probabilities. During the previous study of 425 patients with skin disease, certain epidemiological characteristics of the two groups emerged. The major differences are listed in Table 1.

The factors which were of particular assistance in the diagnosis were the site of the rash and its distribution on the hands, the response to treatment and
TABLE 1

EPIDEMIOLOGICAL CHARACTERISTICS OF THE DERMATITIS AND ECZEMA GROUPS OF PATIENTS

\begin{tabular}{|c|c|c|}
\hline & Dermatitis & Eczema \\
\hline Onset & $\begin{array}{l}\text { Almost invariably during } \\
\text { present employment }\end{array}$ & $\begin{array}{l}\text { In approximately } 20 \% \text { of } \\
\text { cases precedes employ- } \\
\text { ment }\end{array}$ \\
\hline History & Often brief & More often long \\
\hline Age & $\begin{array}{l}\text { Young men more prone } \\
\text { than older men }\end{array}$ & $\begin{array}{c}\text { Relation } \\
\text { marked }\end{array}$ to age not \\
\hline Service & $\begin{array}{l}\text { More often early in employ- } \\
\text { ment }\end{array}$ & $\begin{array}{l}\text { Less marked relation to } \\
\text { duration of employment }\end{array}$ \\
\hline Site & $\begin{array}{l}\text { Exposed parts only in } 80 \text { - } \\
90 \% \text { of cases }\end{array}$ & $\begin{array}{l}\text { Exposed areas in } 60 \% \text { of } \\
\text { cases; other areas also } \\
\text { often involved }\end{array}$ \\
\hline Hands & $\begin{array}{l}\text { Affects dorsum of hand and } \\
\text { webs of fingers }\end{array}$ & Often palms of hands \\
\hline Recovery & Often rapid & Often prolonged \\
\hline Course & $\begin{array}{l}\text { Sickness absence for short } \\
\text { periods } \\
\text { Modified work for short } \\
\text { periods }\end{array}$ & $\begin{array}{l}\text { Sickness absence for long } \\
\text { periods } \\
\text { Modified work for long } \\
\text { periods }\end{array}$ \\
\hline
\end{tabular}

alterations in work, and the relation of the onset to the period of employment.

The term 'folliculitis' was used to describe cases of oil acne and oil folliculitis only. The clinical picture of comedones and pustules, principally affecting the forearms and thighs, is easily recognized and has been well described by Finnie (1960). All gradations are seen, from a small group of blackheads and pustules to a widespread eruption.

A variety of other skin diseases were encountered -acne vulgaris, warts, psoriasis, tinea pedis, pityriasis rosea, and various other conditions, but not more than a few cases of each; they were grouped together as 'miscellaneous'.

At the time the clinical diagnosis was made the disease was also classified as 'trivial', 'moderately severe' or 'severe'. The term 'trivial' was used to describe a scaly or dry eruption of short duration involving only an area of skin less than 1 in. in diameter and not on more than two fingers; or a few comedones with an occasional pustule in patients suffering from folliculitis; or minimal residual lesions in men recovering from more serious attacks of skin disease. 'Moderately severe' lesions were those involving more than two fingers, or a patch of eczema 1-2 in. in diameter. The rash had usually been present for more than one month. Any lesion showing fissuring, lichenification or exudation was usually considered to be at least moderately severe. In seven men the skin disease was classified as 'severe'. In all, the disease had persisted for more than one year and was characterized by frequent relapses; it had caused at least three months' absence from work, and five of the patients were under hospital supervision. 
Results

One thousand two hundred and twenty-three men, representing $97 \%$ of the sample, were examined. Of the 35 whose names were on the original lists but did not attend, most were away from work on account of illness. Their medical records and sickness certificates were traced but none had suffered from skin disease.

TABle 2

PREVALENCE OF FOUR GROUPS OF SKIN DISEASES AMONG 1,223 AUTOMOBILE WORKERS

\begin{tabular}{l|c|c|c|c|c}
\hline \multicolumn{2}{|c|}{$\begin{array}{l}\text { Occupational } \\
\text { Dermatoses }\end{array}$} & \multicolumn{3}{c|}{$\begin{array}{c}\text { Non-occupational } \\
\text { Dermatoses }\end{array}$} \\
\hline Dermatitis & No. & $\%$ & & No. & $\%$ \\
\hline Folliculitis & 53 & $(4 \cdot 3)$ & Eczema & 34 & $(2 \cdot 8)$ \\
\hline Total & 42 & $(3 \cdot 4)$ & Miscellaneous & 49 & $(4 \cdot 0)$ \\
\hline
\end{tabular}

Table 2 shows the prevalence of skin disease among those surveyed. The occupational skin diseases $(7 \cdot 7 \%)$, dermatitis and folliculitis, were only slightly more common than the non-occupational skin diseases $(6.8 \%)$. The miscellaneous skin diseases are listed in detail in Table 3; acne vulgaris, tinea pedis, psoriasis, and warts were the most common of the conditions encountered.

TABLE 3

MISCELLANEOUS SKIN DISEASES ENCOUNTERED IN A SURVEY OF 1,223 WORKERS

\begin{tabular}{l|c|c}
\hline \multicolumn{1}{c|}{ Disease } & No. & $\begin{array}{c}\text { Prevalence } \\
\text { per } 1,000\end{array}$ \\
\hline Acne vulgaris & 10 & $8 \cdot 2$ \\
Tinea pedis & 9 & $7 \cdot 4$ \\
Psoriasis & 5 & $4 \cdot 1$ \\
Warts & 5 & 4.1 \\
Urticaria & 3 & 2.5 \\
Acne rosacea & 2 & 1.6 \\
Sycosis barbae & 2 & 1.6 \\
Varicose ulcer & 2 & 1.6 \\
Naevus of face & 2 & 1.6 \\
Lichen planus & 1 & 0.8 \\
Pityriasis rosea & 1 & 0.8 \\
Others & 7 & $5 \cdot 7$ \\
\hline
\end{tabular}

The survey of patients attending the factory medical department with skin disease had also shown that the number of patients with nonoccupational skin diseases almost equalled the number with occupational skin diseases, but the prevalence rate of skin diseases in the survey was more than four times greater than the attendance rate of patients (Table 4).

The marked discrepancy between the findings might be thought to be due to many of the dermatoses revealed by the survey of workers being of
TABLE 4

COMPARISON OF PREVALENCE RATES AND PATIENT ATTENDANCE RATES AT THE MEDICAL DEPARTMENT FOR THE SAME GROUP OF WORKERS

\begin{tabular}{l|c|c|c}
\hline \multicolumn{1}{c|}{ Disease } & $\begin{array}{c}\text { Prevalence } \\
\text { Rate } \\
\text { (Survey of } \\
\text { Workers 1) } \\
(\%)\end{array}$ & $\begin{array}{c}\text { Patient Attendance } \\
\text { Rate } \\
\text { (Survey of } \\
\text { Patients 2) } \\
(\%)\end{array}$ & $\begin{array}{c}\text { Ratio } \\
1: 2\end{array}$ \\
\hline Dermatitis & $4 \cdot 3$ & $1 \cdot 3$ & $3 \cdot 3$ \\
Folliculitis & $3 \cdot 4$ & 0.4 & 8.5 \\
Eczema & 2.8 & 0.9 & 3.0 \\
Miscellaneous & $4 \cdot 0$ & $0 \cdot 7$ & 5.7 \\
All dermatoses & 14.5 & $3 \cdot 4$ & 4.3 \\
\hline
\end{tabular}

trifling importance. In the survey, $72(40 \%)$ of the dermatoses were classified as trivial, $99(56 \%)$ as moderately severe, and $7(4 \%)$ as severe. Only between one quarter and one third of the affected men were under the care of the factory medical service. Dermatitis and eczema, diseases much feared by an industrial population, were most frequently reported. Folliculitis is often very mild, and unless it causes irritation of the skin it is accepted as an inevitable consequence of working with machine oils, and even extensive rashes are ignored. Many of the workers seen were under the care of their general practitioners as well as the industrial medical officers, but some were only under the care of their own doctors and some, often with long-standing relapsing disease, sought no medical advice at all.

Analysis of Prevalence by Occupation.-There were two main groups of workers, those engaged on actual production, i.e., assemblers and machine operatives, and the stock feeders, cleaners, and inspectors attached to these departments, and the non-production workers, largely employed in stock and store departments.

In the machine shops and on the assembly lines there is a higher proportion of younger, recently employed men than in the non-production departments; production schedules are often exacting, and particularly on the assembly lines the pace is fast and the man's rate of work must be adjusted to the rate of the conveyor belt. Men over 40 years of age tend to transfer to jobs such as packers, sorters, checkers or transport drivers in the stock and store departments where they can work at their own pace. In these departments, too, there is less contact with possible skin irritants such as oils, paints or solvents.

The prevalence of skin disease among workers in the four occupational groups showed some interesting differences (Table 5).

Dermatitis was most frequent among assemblers $(8.6 \%)$ and inspectors, cleaners, and stock feeders attached to the assembly lines $(4.9 \%)$, but it was unexpectedly less common among the machine operatives $(2 \cdot 6 \%)$. After standardization for age, 
TABLE 5

PREVALENCE OF FOUR CATEGORIES OF SKIN DISEASE BY OCCUPATION

\begin{tabular}{l|c|c|c|c|}
\hline & No. Examined & Dermatitis & Folliculitis & Miscellaneous \\
Skin Diseases
\end{tabular}

Percentages are given in parentheses.

* Four patients with dermatitis have been omitted as they were transferred from production work because of skin disease.

$$
\begin{array}{lll}
\text { Tests of Significance (Standardized for Age) } & \text { dermatitis } & \chi^{2}=9.05, \mathbf{P}<0.01 \\
\text { Assemblers } v \text {. non-production workers } & \text { folliculitis } & \chi^{2}=6.21, \mathbf{P}<0.02 \\
\text { Production workers } v \text {. non-production workers } & \text { (n) }
\end{array}
$$

only the assemblers had a significantly higher prevalence than the non-production workers $\left(\chi^{2}=9.05\right.$, $P<0.01)$. In the machine shops the prevalence of folliculitis was high $(5 \cdot 4 \%)$. Those using cutting oils were most often affected. It was also high among the assemblers $(4 \cdot 1 \%)$, who are exposed to lubricating oils and greases, and engine testers who were classified as assemblers and also exposed to engine and diesel oils. The prevalence of folliculitis (also after standardization for age) was significantly higher among production than among non-production workers $\left(\chi^{2}=6.21, P<0.02\right)$.

The prevalence of 'eczema' was slightly, but not significantly, higher among assemblers and machine operatives than among non-production workers. There was little difference in the distribution of the miscellaneous group of skin diseases among the various occupations.
Effect of Age and Length of Service in the Factory.In the previous study of patients reporting to the medical departments of the factory there was a higher proportion of younger than older men with skin disease. In the present survey, however, the prevalence of the four categories of skin disease in relation to age (Table 6) shows that, although folliculitis declines steadily with increasing age, neither the prevalence of eczema nor that of dermatitis shows a constant relationship to age, but dermatitis tends to be more common in men over 56 years. The high prevalence of miscellaneous skin diseases $(11.8 \%)$ among those aged 15 to 25 years was due to the inclusion of many young workers suffering from acne vulgaris.

The prevalence of skin disease according to length of service was also examined. The previous study of

\begin{tabular}{|c|c|c|c|c|c|c|}
\hline Age Group & No. Examined & Dermatitis & Folliculitis & Eczema & $\begin{array}{l}\text { Miscellaneous } \\
\text { Skin Diseases }\end{array}$ & $\begin{array}{l}\text { All Skin } \\
\text { Diseases }\end{array}$ \\
\hline $\begin{array}{l}15+ \\
26+ \\
36+ \\
46+ \\
56+\end{array}$ & $\begin{array}{l}101 \\
332 \\
395 \\
276 \\
114\end{array}$ & $\begin{array}{r}4(4 \cdot 0) \\
16(4 \cdot 8) \\
19(4 \cdot 8) \\
7(2 \cdot 5) \\
7(6 \cdot 1)\end{array}$ & $\begin{array}{r}7(6 \cdot 9) \\
17(5 \cdot 1) \\
13(3 \cdot 3) \\
5(1 \cdot 8) \\
0\end{array}$ & $\begin{array}{r}2(2 \cdot 0) \\
11(3 \cdot 3) \\
10(2 \cdot 5) \\
8(2 \cdot 9) \\
3(2 \cdot 6)\end{array}$ & $\begin{array}{rr}12 & (11 \cdot 8) \\
13 & (3 \cdot 9) \\
10 & (2 \cdot 5) \\
9 & (3 \cdot 3) \\
4 & (3 \cdot 5)\end{array}$ & $\begin{array}{l}25(24 \cdot 7) \\
57(17 \cdot 6) \\
52(13 \cdot 7) \\
29(10 \cdot 5) \\
14(12 \cdot 3)\end{array}$ \\
\hline
\end{tabular}
patients had shown a much higher attendance rate

TABLE 6

PREVALENCE OF FOUR SKIN DISEASES BY AGE GROUP

\begin{tabular}{|c|c|c|c|c|c|c|}
\hline $\begin{array}{l}\text { Service } \\
\text { Group } \\
\text { (yr.) }\end{array}$ & No. Examined & Dermatitis & Folliculitis & Eczema & $\begin{array}{l}\text { Miscellaneous } \\
\text { Skin Diseases }\end{array}$ & $\begin{array}{l}\text { All Skin } \\
\text { Diseases }\end{array}$ \\
\hline $\begin{array}{c}1 \\
1+ \\
2-5 \\
6-10 \\
11-15 \\
16+\end{array}$ & $\begin{array}{r}25 \\
234 \\
213 \\
222 \\
244 \\
280\end{array}$ & $\begin{aligned} & 0 \\
& 12(5 \cdot 1) \\
& 7(3 \cdot 2) \\
& 9(4 \cdot 0) \\
& 15(6.1) \\
& 10(3 \cdot 6)\end{aligned}$ & $\begin{aligned} & 0 \\
& 18(7.6) \\
& 8(3.8) \\
& 6(2 \cdot 7) \\
& 6(2.5) \\
& 4(1.4)\end{aligned}$ & $\begin{array}{r}1(4 \cdot 0) \\
5(2 \cdot 1) \\
2(0.9) \\
9(4.0) \\
7(2.9) \\
10(3 \cdot 6)\end{array}$ & $\begin{aligned} 1(4.0) \\
11(4.7) \\
10(4 \cdot 6) \\
12(5.4) \\
4(1.6) \\
10(3 \cdot 6)\end{aligned}$ & $\begin{aligned} 2(8.0) \\
46(19 \cdot 6) \\
27(12 \cdot 7) \\
36(16 \cdot 2) \\
32(13 \cdot 1) \\
34(12 \cdot 4)\end{aligned}$ \\
\hline
\end{tabular}

The figures in parentheses are percentages.

TABLE 7

PREVALENCE OF FOUR SKIN DISEASES BY LENGTH OF SERVICE

The figures in parentheses are percentages. 
during the first year of employment than at any other time. In the present survey, owing to a recent trade recession only 25 men had had less than one year's service (Table 7). Considering each disease category separately, folliculitis declined steadily with increasing years of service in the factory, but the other categories, 'dermatitis', 'eczema', and the miscellaneous skin diseases, were not obviously influenced by the length of service.

Relation between Prevalence of Skin Disease and Degree of Pigmentation of the Skin.-Some dermatologists have-suggested from their clinical experience that the fair skinned are more sensitive to skin irritants than the darker skinned workers, and that special care should be taken in placing them in jobs where there is a known risk of occupational skin disease (Horner, 1934; Allison, 1957).

The colouring of the eyes, hair, and skin of each worker was recorded during the survey. Hair was graded as fair, brown or black, eyes as blue, hazel or brown, and the complexion as fair, dark or average.

The population was then classified into four groups: (1) men with fair skin, fair hair, and blue eyes; (2) men with a fair skin but with hazel or brown eyes and fair, brown or black hair; (3) all men with an average skin colour; and (4) all men with dark skin.

All the men in this series were Europeans. The occurrence of skin disease was inversely related to the degree of pigmentation of the group. The same trend was found in both the occupational and nonoccupational groups of skin diseases. The association between the degree of pigmentation and the prevalence of skin disease was statistically significant at the $5 \%$ level of confidence (Table 8).

During an investigation of new entrants at another branch of the factory an opportunity arose to compare the prevalence of skin disease in 211 Europeans and in $\mathbf{1 3 0}$ workers from the West Indies and Asia, all doing similar work and fairly evenly matched for age and length of service. Among the Europeans the same trends were observed as in the larger survey,
TABLE 8

PREVALENCE OF SKIN DISEASES IN EUROPEAN MEN OF DIFFERING PIGMENTATION

\begin{tabular}{l|c|cc}
\hline \multicolumn{1}{c|}{ Colouring } & No. Examined & $\begin{array}{l}\text { No. with } \\
\text { Skin Disease }\end{array}$ \\
\hline $\begin{array}{l}\text { Blue eyes } \\
\text { Fair hair } \\
\text { FAIR SKIN }\end{array}$ & 236 & $43 \quad(18.2 \%)$ \\
\hline $\begin{array}{l}\text { Hazel/brown eyes } \\
\text { Brown/black hair } \\
\text { FAIR SKIN }\end{array}$ & 234 & 37 & $(15.8 \%)$ \\
\hline \begin{tabular}{l} 
AVERAGE SKIN \\
\hline DARK SKIN
\end{tabular} & 655 & 87 & $(13 \cdot 3 \%)$ \\
\hline
\end{tabular}

$x^{2}=3.95$ on 1 degree of freedom, $\mathrm{P}<0.05$

TABLE 9

PREVALENCE OF SKIN DISEASES IN TWO RACIAL GROUPS

\begin{tabular}{|c|c|c|c|}
\hline & No. Examined & & $\begin{array}{l}\text { with } \\
\text { Disease }\end{array}$ \\
\hline $\begin{array}{l}\text { Europeans } \\
\text { West Indian and Asiatic }\end{array}$ & $\begin{array}{l}211 \\
130\end{array}$ & $\begin{array}{r}47 \\
4\end{array}$ & $\begin{array}{l}(24.4 \%) \\
(3.0 \%)\end{array}$ \\
\hline
\end{tabular}

with fair men being more prone to develop skin disease than darker men; but, whereas $47(24 \%)$ of the European workers were suffering from some type of skin disease, only four $(3 \%)$ of the West Indian and Asiatic group had a skin rash (Table 9).

Association of Skin Disease with a History of Eczema, Hay Fever and Asthma.-Each worker was asked whether he or anyone in his family (parents, aunts, uncles, siblings or children) suffered from asthma or hay fever. A family or personal history of asthma and/or hay fever appeared to be more frequent among the workers included in the 'eczema' group than among those suffering from 'dermatitis', 'folliculitis', and other skin diseases or the unaffected workers (Table 10). However, there was no significant difference between the number of positive histories either when the 'eczema' group was compared with the 'dermatitis' group or when it was compared with the group unaffected by skin disease.

TABLE 10

HISTORY OF ASTHMA AND/OR HAY FEVER IN MEN WITH AND WITHOUT SKIN DISEASE

\begin{tabular}{|c|c|c|c|c|}
\hline Category & No. Examined & $\begin{array}{c}\text { Personal History only } \\
\text { Positive }\end{array}$ & $\begin{array}{c}\text { Family History only } \\
\text { Positive }\end{array}$ & $\begin{array}{c}\text { Personal and Family } \\
\text { Histories } \\
\text { Positive }\end{array}$ \\
\hline $\begin{array}{l}\text { Eczema } \\
\text { Dermatitis } \\
\text { Folliculitis } \\
\text { Miscellaneous skin diseases } \\
\text { Unaffected }\end{array}$ & $\begin{array}{r}34 \\
53 \\
42 \\
49 \\
1,045\end{array}$ & $\begin{aligned} & 1(2 \cdot 9) \\
& 2(3 \cdot 8) \\
& 1(2 \cdot 3) \\
& 2(4 \cdot 1) \\
& 40(3 \cdot 8)\end{aligned}$ & $\begin{array}{rr}5 & (14 \cdot 7) \\
5 & (9 \cdot 4) \\
4 & (9 \cdot 5) \\
3 & (6 \cdot 1) \\
74 & (7 \cdot 0)\end{array}$ & $\begin{array}{l}2(5 \cdot 9) \\
0 \\
1(2 \cdot 3) \\
0 \\
9(0 \cdot 9)\end{array}$ \\
\hline Total & 1,223 & $46(3 \cdot 8)$ & $91(7 \cdot 4)$ & $12(1 \cdot 0)$ \\
\hline
\end{tabular}

The figures in parentheses are percentages. 


\section{Discussion}

Only about half of the skin diseases encountered in this automobile factory were considered to be occupational. Causes of 'dermatitis' were not infrequently recognized, for example, friction over the knuckles from a plastic glove or contact with paraffin or trichlorethylene. Among the assemblers, where the prevalence of 'dermatitis' was significantly higher than in the non-production group, subsequent study revealed that dermatitis due to sensitization with potassium dichromate was common (Newhouse, 1963). For many years a potassium dichromate dip had been used in plating nuts, bolts, and screws in use on the assembly lines. A modification of the process by omitting the dichromate dip in one assembly section was followed by a substantial reduction in the prevalence of 'dermatitis' (Newhouse, 1964).

The occurrence of folliculitis was related both to the type of oil and to the degree of exposure. This was highest among men using insoluble cutting oils as a coolant in machining. An engineering modification, which eliminated an oil spray contaminating the operative, was followed by a marked drop in the incidence of folliculitis.

The prevalence of 'eczema' showed no occupational bias. A study of patients with endogenous eczema showed that the course of the disease was often severe. A comparison of these patients with those diagnosed as suffering from 'dermatitis' showed that the endogenous group had longer periods of sickness absence and more frequently required modifications of their jobs.

Four per cent of the workers examined were suffering from skin diseases included in the miscellaneous group; apart from tinea pedis, which sometimes gave rise to troublesome epidermophytid reactions on the hands, they gave rise to little disability and were an infrequent cause of sickness absence.

Wilson (1961) found a higher incidence of both dermatitis and patchy or discoid eczema among manual than among non-manual workers. All men seen in the present survey were manual workers, although those employed in the stock and store departments were considered to be less exposed to dermatitic agents than the production workers. Only among the assemblers, where a specific skin-sensitizing agent was found, was the prevalence of dermatitis significantly higher than in the nonproduction workers. However, all workers seen in this survey were exposed to some extent to dirt, oils, friction, and minor traumata. It is these factors that are responsible for the occurrence of occupational dermatitis in the non-production group.
The survey confirmed the clinical finding that fair skinned individuals are more prone to skin disease than the darker skinned, and this should be borne in mind in the placement of workers in jobs such as chrome plating or work with epoxide resins where dermatitis is a recognized hazard.

Reports on patients seen for compensation purposes by Hellier (1958), Vickers (1958), and Skög and Tottie (1961) and sickness absence statistics indicate that occupational dermatitis most commonly occurs at about 40 years of age. This survey reveals that the prevalence, if not the severity, of occupational skin disease is at least as high in the men under 40 years.

So few workers had been employed for less than one year that it was not possible to confirm or disprove the previous finding that occupational dermatitis occurs most commonly in the first few months of employment (Newhouse, 1961). Folliculitis, however, was obviously more prevalent among the younger and more recently employed persons.

Bettley (1949), discussing the decrease in the amount of skin disease commonly observed to occur after the first few months of employment and referred to as 'hardening', states that it is due to 'improvements in work techniques, avoidance of excessive contact and increase in personal cleanliness'.

The group of newly employed workers, the majority of whom are under 30 years of age, would benefit from a training in hygiene and the use of common protective devices.

That more than two-thirds of the men with skin disease did not seek treatment from the factory medical service, and that some with long-standing disease sought no medical advice at all, indicates a need for education and routine surveillance of special groups such as the elderly and those who have been absent from work with skin disease.

From the results of this survey it can be estimated that in any similar industrial community, in addition to about 80 per 1,000 with occupational skin disease, there are likely to be nearly 30 per 1,000 with endogenous eczema, a group also requiring medical supervision at their place of work.

Gratefulacknowledgement is made to the managements, workers, and medical and nursing staff of the Ford Motor Company at Dagenham for their co-operation and assistance. My thanks are also due to Professor C. D. Calnan and Professor R. S. F. Schilling for their advice and encouragement, and to Miss Joan Walford for statistical assistance.

A preliminary report on this survey was originally communicated to the Society of Social Medicine in September, 1962 and has been summarized in the British Journal of Preventive and Social Medicine (1962, 16, 51). 


\section{REFERENCES}

Allison, J. R. (1957). J.S.C. med. Ass., 53, 208.

Bettley, F. R. (1949). Skin Diseases in General Practice, Eyre \& Spottiswoode, London.

Finnie, J. S. (1960). Brit. J. industr. Med., 17, 130.

Hellier, F. F. (1958). Brit. med. J., 1, 196.

Horner, S. G. (1934). Trans. and 23 rd Ann. Rep. St John's Hosp. derm. Soc. (Lond.), No. 23, p. 37.
Industrial Dermatitis (1962). Ministry of Labour. Safety, Health and Welfare, New Series No. 18. H.M.S.O., London.

Newhouse, M. L. (1961). Trans. St John's Hosp. derm. Soc. (Lond.),

No. 47, p. 139.
(1963). Brit. J. industr. Med., 20, 199.

- (1963). Brit. J. industr. Med., 20, 199.

- (1964). Trans. Ass. industr. med. Offrs, in the press.

Skög, E., and Tottie, M. (1961). Acta derm.-venereol. (Stockh.), 41, Vickers, H. R. (1958). Brit. med. J., 1, 199.

Wilson, H. T. H. (1961). Trans. St John's Hosp. derm. Soc. (Lond.) 